\title{
Serological and parasitological study and report of the first case of human babesiosis in Colombia
}

\author{
Estudo sorológico e parasitológico e relato do primeiro caso \\ de babesiose humana na Colômbia
}

Leonardo Ríos ${ }^{1}$, Gonzalo Alvarez ${ }^{1}$ and Silvia Blair ${ }^{1}$

\begin{abstract}
A study on the presence of Babesia in humans was performed in Puerto Berrío (Latitude 6.50deg. Longitude: -74.38deg. River: Magdalena. Area: $74.410 \mathrm{~km}^{2}$, Colombia-South America). Indirect immunofluorescence, thin and thick blood smears were used to study 194 individuals. Patients were grouped according to their riskfactors for Babesia infection: (group 1) individuals with fever, chills, sweating and other malaria-type symptoms; (group 2) symptomatic and asymptomatic individuals from local cattle ranches, which were enrolled in an active form, and (group 3) workers from the local slaughterhouse. Seven individuals were serologically positive for Babesia: Three individuals presented IgM antibodies against B. bovis, while one had Ig G against this species; one individual had IgM against $\mathrm{B}$. bigemina, another had Ig $\mathrm{G}$ and a third both IgM and IgG against this species. Only one individual was parasitologically positive for Babesia and serologically positive for Babesia bovis (IgM 1:64)
\end{abstract}

Key-words: Babesia. Indirect immunofluorescence antibody test (IFA). Blood smear. Malaria. Human babesiosis.

Resumo O estudo realizado avaliou a presença de Babesia em pessoas do município de Puerto Berrío (Latitude:6.50 graus. Longitude: -74,38 graus. Rio: Madalena. Área: $74.410 \mathrm{~km}^{2}$, Colômbia, América do Sul). Utilizou-se a inmunofluorescência indireta, a gota espessa e o esticado de sangue para avaliar 194 indivíduos. As pessoas foram distribuidas em grupos segundo seus fatores de risco à infecção com Babesia. Grupo1: indivíduos com febre, calafrio, sudorese e outros sintomas associados à malária; Grupo 2: indivíduos residentes em fazendas de gado e que apresentavam ou não, sintomas associados à infecção; Grupo 3: trabalhadores do abatedouro da localidade. Os resultados mostraram sete pessoas com sorologia positiva para Babesia, das quais três tinham anticorpos IgM contra B. bovis, uma apresentou anticorpos Ig G contra dita espécie; um indivíduo teve anticorpos IgM contra B. bigemina, outro teve anticorpos Ig $G$ e um terceiro apresentou tanto anticorpos IgM quanto lg G contra essa espécie. Só em uma das pessoas avaliadas houve resultados parasitológicos e sorológicos positivos para Babesia bovis (IgM 1:64).

Palavras-chaves: Babesia. Inmunoflourescência indireta. Gota espessa. Malária. Babesiose humana.

Babesiosis is an infection produced by protozoan parasites of the genus Babesia, which naturally infect mammals, birds, reptiles and amphibians. Bovine babesiosis is a prevalent disease in the malaria endemic regions of Colombia, and is produced by Babesia bigemina and Babesia bovis ${ }^{1021}$.

In medical history, the first case of human babesiosis was described in 1957 by Skrabalo and Deanovic in Yugoslavia, in a splenectomized farmworker who presented malaria symptoms. The patient died and afterwards a bovine Babesia was confirmed in blood smears ${ }^{23}$.

Human babesiosis is a zoonosis clinically similar to malaria, it is transmitted by a tick-bite ${ }^{32}$. The etiological agent and laboratory diagnosis are notoriously similar to those of human malaria' 19171920282930 . This created confusion when the first cases of human babesiosis were diagnosed and reported 122023 .

In Colombia, there are areas where eco-epidemiologic risk-factors for malaria and human babesiosis converge

1. Grupo Malaria, Universidad de Antioquia, Medellín-Colombia.

Address to: Dra. Silvia Blair T. Kra 51-D \# 62-29, AA: 1226, Medellín Colombia.

Telephone: (574) 510-6058, Fax (574) 263-3509

e-mail: sblair@catios.udea.edu.co

Recebido para publicação em 10/9/2003

Aceito em 12/6/2003 
and overlap. Furthermore, there is an important percentage of patients with malaria symptoms and negative blood smears for malaria. Therefore, the main purpose of our work was to study the presence of infection by Babesia bovis and Babesia bigemina in humans in a malaria and bovine babesiosis endemic region using an epidemiological, parasitological and serological approach.

\section{MATERIAL AND METHODS}

Groups studied. The study was carried out using a descriptive and transversal design. 194 inhabitants of Puerto Berrío (locality of Colombia) were included. Participants were distributed in three groups according to their epidemiological risk-factors for human babesiosis; the first group consisted of 10 male adults with symptoms of malaria who sought treatment at the local hospital presenting fever, chills, sweating, and headache. The second group comprised 134 male adults, with or without malaria symptoms. All individuals of these two groups were working at local farms and had direct contact with cattle for a year or more. All individuals from the second group were enrolled in an active form. A third group was constituted by 50 individuals, of which 45 were employed at the local slaughterhouse, where they were in close contact with tissues, secretions, blood and viscera of cattle originating from local ranches. The remaining 5 individuals were veterinarians working in the area and in close contact with cattle during palpation, birth, surgery, and other work. All procedures performed in this study were in accordance with the standards of the ethical committee of Universidad de Antioquia, defining human experimentation and based on the 1975 Helsinki Declaration, as revised in $52^{\text {nd }}$ The World Medical association General Assembly, Edinburgh, Scotland, October 2000.

Babesiosis diagnosis. Parasitological diagnosis of Babesia was based on the finding of compatible forms in thin blood smear. Indirect immunofluorescence antibody (IFA) was used for serological diagnosis.

Diagnosis of active babesiosis was based on positive results in both tests. The diagnosis of previous contact with Babesia, was based on the presence of antibody titers $\geq 1: 32$ for $\lg ^{15} 27$.

Parasitological study. Capillary blood was obtained in triplicate and thick and thin blood smears were Field and Giemsa stained respectively ${ }^{19}{ }^{26}$. Samples were evaluated at the Laboratorio de Hemoparásitos of Universidad de Antioquia. All slides were negative for malaria. Slides with suspected babesiosis were evaluated by experts in bovine babesiosis at CORPOICA (Corporación del Instituto Colombiano Agropecuario Santafé de Bogotá, Colombia). The presence of pyriform parasites in pairs or tetrads without pigment was considered as positive for Babesia. Likewise, detection of circular or ovoid forms with differentiated chromatin and cytoplasm without pigment was also considered positive.

Serological study. Antigen preparation for IFA test for Babesia bovis and Babesia bigemina was obtained from $<1$ year old splenectomized calves, some of which were infected with the Australian strain of
Babesia bovis and others with the Bv V1 strain of $B$. bigemina, donated by the Epivet germ plasm (CORPOICA). At peak parasitemia, blood was collected in test tubes with heparin, then washed with PBS ( $\mathrm{pH} 7.2-7.3)$, and the layer of white blood cells was removed. Hematocrit was adjusted to $30 \%$ using $4 \%$ bovine albumin, and then parasitemia was adjusted to $25 \%$ in the case of $B$. bovis and $35 \%$ for $B$. bigemina. Thin blood smears were prepared and air-dried at $30^{\circ} \mathrm{C}$ for 30 to 45 minutes, these were then covered with aluminum foil and stored at $-20^{\circ} \mathrm{C}$.

Conjugate titration: due to lack of a positive human serum for Babesia bovis and Babesia bigemina a direct immunofluorescence technique was used for the titration of the conjugate. Concentrated human red blood cells were used as antigen. The slides were airdried and an IgG or IgM conjugate was added. Fluorescein was added at different dilutions from 1/20 to $1 / 400$, optimal dilutions were $1 / 200$ for $\operatorname{lgM}$, and 1/ 100 for lgG.

Antibody titration: IFA test for IgG and IgM was performed following the technique of Hijmans et al 1970 ${ }^{14}$; serum dilution started at $1: 16^{6}$. IgG and $\operatorname{lgM}$ titers were considered positive when dilution $\geq 1: 32$ showed a clear fluorescence of the antigen within red blood cells ${ }^{15} 27$. Immunofluorescence was read using the simple-blind method, in which researchers were not aware of the patient's condition and had access only to serum samples and to thick and thin blood films. In order to exclude cross-reactions, IFA and ELISA tests for malaria were performed in all positive Babesia bovis and Babesia bigemina samples.

Malaria IFA: the technique of Hijmans et al $1970^{14}$ was used. $P$. falciparum schizonts (FCB-2 strain) were used as antigen. They were separated by Percoll. Samples were read in a Leitz fluorescence microscope. Titers higher than 1:16 for IgG and 1:32 for $\operatorname{lgM}^{67}$ were considered as positive.

Malaria ELISA: crude P. falciparum schizont extracts was obtained after 2 minutes of sonication at $25 \mathrm{~W}$ (Branson Sonifier Mod. 200). Protein concentration was measured using $1000 \mu \mathrm{g} / \mathrm{mL}$ of Bradford reactive (BioRad, Hercules, California). Standardization of the technique was performed at 1.0, 2.5, 5.0, 7.5 and 10 $\mu \mathrm{g} /$ $\mathrm{mL}$ of the reactive in carbonate buffer (concentration of $1000 \mu \mathrm{g} / \mathrm{mL}$ ) on 96 wells $U$ button plates (Nuclon, Denmark), and a concentration of $5 \mu \mathrm{g} / \mathrm{mL}$ was chosen for performance of the ELISA test. $100 \mu \mathrm{g} / \mathrm{mL}$ of the antigen were plated and incubated for one hour at $37^{\circ} \mathrm{C}$ and then overnight at $4^{\circ} \mathrm{C}$. The wells were washed with PBS and 0.05\% Tween 20 (J.T.Baker, Deventer, 
Holland). $100 \mu \mathrm{g} / \mathrm{mL}$ of $\mathrm{PBS} / 5 \%$ bovine albumin were added and incubated for one hour at $37^{\circ} \mathrm{C}$. Finally, plates were washed with PBS 0.05\% Tween 20 (J.T.Baker).

Negative and positive controls were evaluated as a pure sample and at dilution of $1: 32$ in two fold dilutions in PBS 1\% bovine albumin (BSA). The antigen on 96 well U-bottom plates was incubated for an hour at $37^{\circ} \mathrm{C}$. Plates were washed 5 times with PBS $0.05 \%$ Tween 20 (JT Baker) and the anti-IgM alkaline phosphatase conjugated was added at a dilution of
$1: 20000$ in PBS $1 \%$ BSA. The anti-IgG alkaline phosphatase conjugated at 1:1000 in PBS 1\% BSA. Samples were incubated for an hour at $37^{\circ} \mathrm{C}$ and washed 5 times with PBS $0.05 \%$ Tween 20 (JT Baker). P-Nitrophenyl Phosphate (Sigma, St. Louis, USA) was added as substrate and incubated for 45 minutes at room temperature. Reaction was stopped with $\mathrm{NaOH}$ $2 \mathrm{~N}$ and absorption was measured in an ELISA reader (Titertek-Uniskan II) at $405 \mathrm{~nm}$. The cutoff point of reactivity was determined at titers $\geq 1: 32$.

\section{RESULTS}

Parasitological findings. One individual out of 194, presented parasite forms compatible with Babesia, described as follows: A pyriform parasite, resembling a trophozoite, which was found in a 100X microscopic field, although differentiation of the chromatin was insufficient, it was compatible with Babesia. An

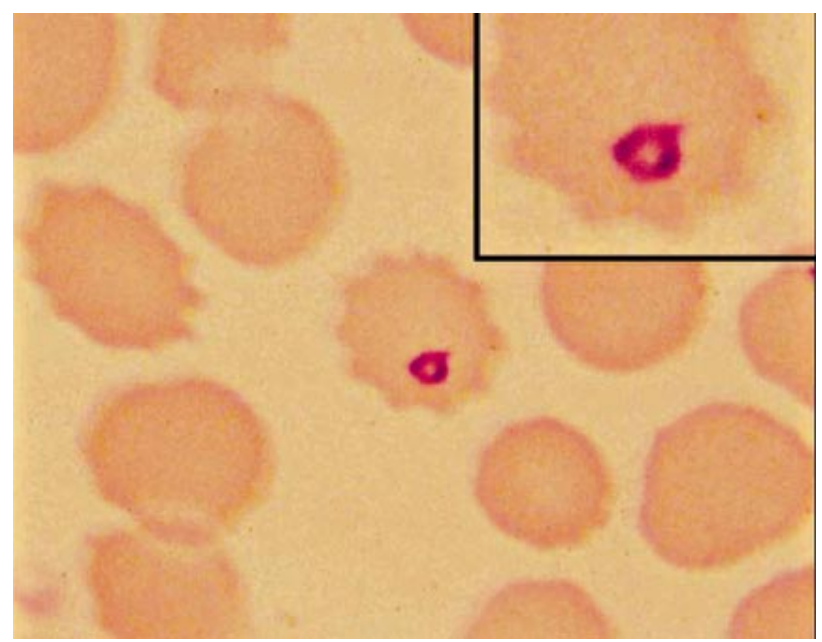

Figure 1 - Microphotography of pyriform parasite in pairs without pigment of Babesia sp in human red blood cell from patients

Serological findings. Seven individuals (3.6\%) had positive titers, two for $\lg G$, four for $\lg M$ and one for both IgG and IgM. Titers varied between 1:32 and 1:128 (Table 1). The most relevant features of these patients are shown in Tables 1 and 2 .

The IFA test for malaria was positive in patient number 4, who was also positive for Babesia bovis $\lg$ (1:64) The other six individuals seropositive for Babesia bovis and/or B. bigemina were negative for malaria antibodies. In the ELISA test, all tested individuals were negative for malaria IgM (Table 3).

Clinical and epidemiological description in patient number 1 with Babesia bovis: the patient was a 37year-old male, who presented at the local hospital with intermittent fever (without periodicity), chills, sweating, weakness and bone ache; a thick smear was negative aggregate was observed in another field, corresponding to four parasites within a red blood cell, each one had a pear-shaped trophozoite; with adequate chromatin differentiation; this form is known as Maltese Cross and is considered to confirm the diagnosis of infection by Babesia. (Figures 1 and 2)

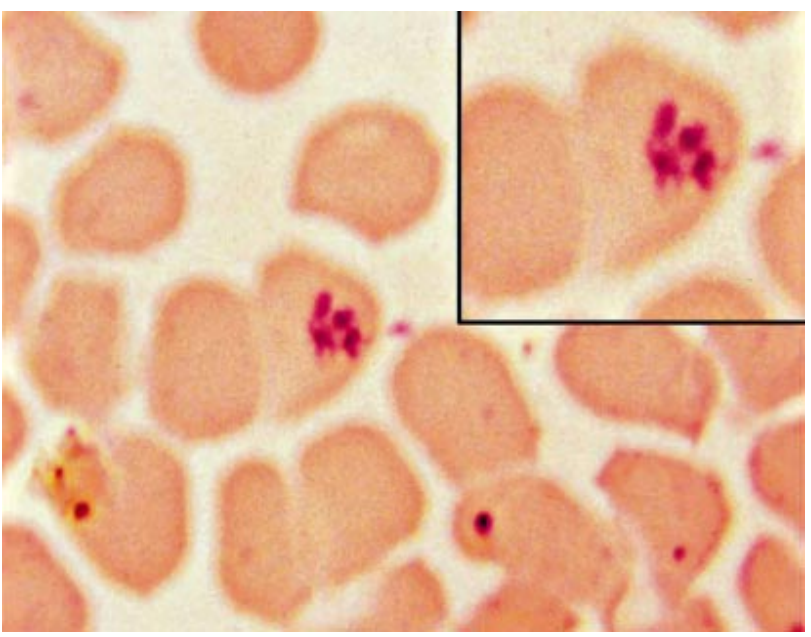

Figure 2 - Microphotography of pyriform parasites in tetrad without pigment (Maltese Cross) of Babesia sp in human red blood cell from patients (100X);
(electronically enhanced).

Table 1- Parasitological and serological description of the seven Babesia positive individuals.

\begin{tabular}{|c|c|c|c|c|c|c|c|}
\hline \multirow{3}{*}{$\begin{array}{l}\text { Individual } \\
\text { No. }\end{array}$} & \multirow{3}{*}{$\begin{array}{l}\text { Age } \\
\text { (years) }\end{array}$} & \multirow[b]{3}{*}{ Symptoms } & \multirow[b]{3}{*}{ Paras. } & \multicolumn{4}{|c|}{ Antibody titers (+) } \\
\hline & & & & \multicolumn{2}{|c|}{ B. bovis } & \multicolumn{2}{|c|}{ B. bigemina } \\
\hline & & & & $\lg G$ & $\lg M$ & $\lg G$ & $\lg M$ \\
\hline $1^{*}$ & 37 & if, c, s, w, bm & + & 0 & $1 / 64$ & 0 & 0 \\
\hline 2 & 25 & asymptomatic & - & 0 & $1 / 128$ & 0 & 0 \\
\hline 3 & 24 & i.f, $c, s$ & - & 0 & $1 / 128$ & 0 & 0 \\
\hline 4 & 18 & asymptomatic & - & $1 / 64$ & 0 & 0 & 0 \\
\hline 5 & 49 & headache & - & 0 & 0 & $1 / 128$ & $1 / 128$ \\
\hline 6 & 60 & asymptomatic & - & 0 & 0 & 0 & $1 / 32$ \\
\hline 7 & 39 & asymptomatic & - & 0 & 0 & $1 / 64$ & 0 \\
\hline
\end{tabular}

${ }^{*}$ Patient who attended the Hospital; the remaining participated in an active form.

All participants live in the city of Puerto Berrío, Colombia

if: intermittent fever, c: chills, s: sweating, w: weakness, bm: bone malaise, c.s: cold symptoms 
Table 2 - Epidemiological features of positive individuals.

\begin{tabular}{lcclcc}
\hline Indiv. (no.) & Group (no.) & Work in months & Work type & Tick-bites (no.) & Malaria (history) \\
\hline 1 & 1 & 240 & chainsaw operator & 3 & 0 \\
2 & 2 & 144 & milker & mone & none \\
3 & 2 & 144 & mower, fumigator and mower operator & 0 & none \\
4 & 2 & 48 & administrator, milker, cowboy and fumigator & $>6$ & none \\
5 & 2 & 360 & cowboy, hunter and fisherman & $>6$ & none \\
6 & 2 & 420 & milker, cowboy and grass cutter & 0 & none \\
7 & 2 & 240 & none
\end{tabular}

Chainsaw operator: person who works with a power saw used in tree surgery and logging.

Milker: person who milks the cows, manually or using a machine.

Mower: person who cuts the grass or grain with a portable machine.

Cattle locking-up worker: person who rounds up the cattle or encloses each animal for treatment or any other purpose.

Grass cutter: person who uses a machete to cut grass, corn or other animal food material.

Fumigator: person who disinfects or purifies with smoke, either the pasture or the cattle.

Table 3 - Anti-Plasmodium antibodies versus anti-babesia antibodies.

\begin{tabular}{|c|c|c|c|c|c|}
\hline & \multicolumn{3}{|c|}{ Babesiosis } & \multicolumn{2}{|c|}{ Malaria } \\
\hline & \multicolumn{3}{|c|}{ IFA } & IFA & ELISA \\
\hline & individuals* & $\lg G$ & $\lg M$ & $\lg G$ & $\lg M$ \\
\hline \multirow[t]{4}{*}{ Babesia bovis } & 1 & neg & $1 / 64$ & neg & neg \\
\hline & 2 & neg & $1 / 128$ & neg & neg \\
\hline & 3 & neg & $1 / 128$ & neg & neg \\
\hline & 4 & $1 / 64$ & neg & positive & neg \\
\hline \multirow[t]{3}{*}{ Babesia bigemina } & 5 & $1 / 128$ & $1 / 128$ & neg & neg \\
\hline & 6 & neg & $1 / 32$ & neg & neg \\
\hline & 7 & $1 / 64$ & neg & neg & neg \\
\hline
\end{tabular}

for malaria. The patient worked for 20 years as a chainsaw operator. At the time of consultation, he was working at a cattle ranch located in the rural area. He reported remembering tick bytes on three occasions, and he did not have history of malaria (Table 2). His serological study showed antibodies for Babesia bovis $\lg M(1: 64)$, negative anti-malarial IgM antibodies by ELISA and negative by IFA (Table 3).

\section{DISCUSSION}

We report the first case of human babesiosis in Colombia which was parasitologically confirmed by positive blood films for Babesia and antibody titers positive for Babesia bovis (IgM 1:64), in a patient who presented intermittent fever, chills and sweating lasting several days. These findings have been reported in the medical literature as characteristic of the acute phase of the disease, as confirmed by positive lgM titers ${ }^{15} 27$.

Six other individuals were positive by serology for Babesia, three for Babesia bovis and three for Babesia bigemina. Two of those patients (patients number 4 and number 7) were IgG positive and asymptomatic, which can be explained by a possible prior infection; two were IgM positive and symptomatic (patients number 3 and $5)$ and two patients had positive IgM titers and absence of symptoms (patients number 2 and 6), which can be explained by a subacute phase of the infection (Table 1).

Coexistence of positive anti-Babesia antibodies and positive anti-Plasmodium antibodies suggest the possibility of co-infection by both parasites. This has been reported previously in humans in the case of
Babesia microti and Borrelia burdogferi ${ }^{16} 20$. Similarly, cross-reactivity by IFA among parasites of the phylum Apicomplexa, including Babesia bovis and Plasmodium falciparum has been reported ${ }^{8} 1824$. Patients number 4 could have either a cross reactivity or co-existing antibody IgG for both Babesia and Plasmodium parasites.

Suarez et al conducted the first study on seroprevalence of human Babesia bovis and Babesia bigemina in the province of Ciego de Avila, Cuba. Suarez used the IFA test in 781 samples. Titers for IgG positive antibodies were established as (1:64), 7\% positivity was found in workers of cattle ranches and $3.9 \%$ in blood donors coming from the same area, compared to $3.6 \%$ seroprevalence for antibabesia antibodies in the studied population comprising cattle ranch workers ${ }^{27}$.

Working in close contact with organic fluids and viscera of possibly infected animals, can not be defined as a direct risk-factor for infection by Babesia bovis and/or Babesia bigemina, since in this study no positive individuals were found in group 3 . 
Worldwide, the IFA test is the most used technique, to determine evidence of contact between humans and Babesia' 12152425 . It is necessary, however, to use molecular techniques to identify the species, since it is known that the morphological features alone do not offer accurate criteria and that the changes in the parasite's morphology are variable in the infected host ${ }^{11} 132223$.
Human babesiosis is present in Puerto Berrío. The first case of human babesiosis in Colombia is presented here and confirmed by parasitological and serological studies. Furthermore, we have reported the first six cases of human babesiosis detected by the IFA test.

\section{ACKNOWLEDGEMENTS}

These study was supported by Dirección Seccional de Salud de Antioquia (DSSA) and the Universidad de Antioquia. We are grateful to the Committee of ranchers of Puerto Berrío, the Colombian Institute for farming and animal husbandry (Instituto Colombiano agropecuario ICA, CORPOICA) and inhabitants of Puerto Berrío. Special thanks to Mrs. Adriana Pabón and her family, to Claudia Milena Brito, Efraín Benavides and Juan M. Castillo.

\section{REFERENCES}

1. Allred DR. Immune evasion by Babesia bovis Plasmodium falciparum: Cliff-dwellers of the parasite world. Parasitology Today 11: 100-104, 1995

2. Benach JL, Coleman JL, Habitch GS, Macdonald A, Grunwaldt E and Giron JA. Serological evidence for simultaneous occurrence of Lyme disease, babesiosis. Journal of Infection Disease 152: 473-477, 1985.

3. Cahill KM. Babesiosis: Unappreciated even in endemic areas. Journal of Community Health 20: 315-320, 1995.

4. Corrier DE, Cortez JM, Thompson KC, Riaño H, Becerra E, Rodriguez RA. Field survey of bovine anaplasmosis, babesiosis and tick vector prevalence in the eastern plains of Colombia. Tropical Animal Health and Production 10: 91-92, 1978.

5. Dammin GJ, Spielman A, Benach JL, Piesman J. The rising incidence of clinical Babesia microti infection. Human Pathology 12:398-400, 1981.

6. Ferreira AW. Inmunodiagnóstico de malaria. In: López-Antuñano FJ, Schmunis G (eds) Diagnóstico de malaria. Publicación Científica 512. Organização PanAmericana de Saúde Washington, p. 65-75,1988a.

7. Ferreira AW. Técnicas de Laboratorio. Detección de anticuerpos. In: López-Antuñano FJ, Schmunis G (eds) Diagnóstico de malaria. Washington: Publicación Científica 512. Organização PanAmericana de Saúde p. 76-78, 1988b.

8. Gelfand JA. Babesia. In: Mandell GL, Douglas RG, Bennett JE. (eds) Enfermedades Infecciosas. Principios y prácticas, Argentina: Panamericana $\left(3^{\text {th }}\right)$, p. 2249-2253,1991.

9. Gombert ME, Goldstein EJ, Benach JL, Tenenbaum MJ, Grunwaldt E, Kaplan MH, Eveland LK. Human babesiosis. Clinical and therapeutic considerations. Journal of the American Medical Association 248: 3005-3007, 1982.

10. Gonzalez EF, Corrier DE, Todorovick RA, López G. Epidemiología e impacto económico de la anaplasmosis en el valle geográfico del río Cauca. Revista Colombiana de Ciencias Pecuarias 1: 201-207, 1978.

11. Healy GR, Ruebush II T.K. Morphology of Babesia microti in human blood smears. American Journal of Clinical Pathology 73: 107-109, 1980.

12. Healy GR, Walzer PD, Sulzer AJ. A case of asymptomatic babesiosis in Georgia. American Journal of Tropical Medicine and Hygiene 25: 376-378, 1976.
13. Herwaldt BL, Persing DH, Precigout EA, Goff WL, Mathiesen DA, Taylor PW, Eberhard ML, Gorenflot AF. A fatal case of another piroplasm that infects humans. Annals of Internal Medicine 124: 643-650, 1996.

14. Hijmans W, Schuit HRE, Jongsma APM, Ploem JS. Performance Testing of fluorescent antisera against human immunoglobulins. In: Holbosow EJ (ed) Standardization in immunofluorescence. Blackwell Scientific Publications. Oxford, p. 193-202, 1970.

15. Krause PJ, Telford III SR, Ryan R, Conrad PA, Wilson M, Thomford JW, Spielman A. Diagnosis of babesiosis: Evaluation of a serologic test for the detection of Babesia microti antibody. Journal of Infectious Disease 169: 923-926, 1994.

16. Krause PJ, Telford III SR, Spielman A, Sikand V, Ryan R, Christianson D, Burke G, Brassard P, Pollack R, Peck J, Persing $\mathrm{DH}$. Concurrent Lyme disease and babesiosis. Evidence for increased severity and duration illness. Journal of the American Medical Association 275:1657-1660, 1996.

17. Kreier JP, Ristic M. Introduction. Malaria and Babesiosis. $3^{\text {rd }}$ International Congress. Transactions of the Royal Society of Tropical Medicine and Hygiene 83 (Suppl I), 1989.

18. Ludford CG, Hall WTK, Sulzer AJ, Wilson M. Babesia argentina, Plasmodium vivax and P. falciparum: Antigenic cross-reactions. Experimental. Parasitology 32: 317-326, 1972.

19. Marcus LC, Valigorsky JM, Fanning WL, Joseph T, Glick B. A case report of transfusion - induced babesiosis. Journal of the American Medical Association 248:465-467, 1982.

20. Marcus LC, Steere AL, Duray PH, Anderson AE, Mahoney EB. Fatal pancarditis in a patient with coexistent Lyme disease and babesiosis. Annals of Internal Medicine 103: 374-376, 1985.

21. Mateus G. Epizootiología de la babesiosis bovina en el piedemonte, área de Villavicencio. Revista ICA (Bogotá) 22: 42-54, 1987.

22. Persing DH, Herwaldt BL, Glaser C, Lane RS, Thomford JW, Mathiesen D, Krause PJ, Phillip DF, Conrad PA. Infection with a Babesia-like organism in Northern California. The New England Journal of Medicine 332: 298-303, 1995.

23. Pruthi RK, Marshall WF, Wiltsie JC, Persing DH. Subspecialty Clinics: Infectious Diseases. Human babesiosis. Mayo Clinical Proceedings 70: 853-862, 1995.

24. Ruebush II TK, Cassaday PB, Marsh HJ, Lisker SA, Voorhees DB, Mahoney EB, Healy GR. Human babesiosis on Nantucket Island. Annals of Internal Medicine 96: 6-7, 1977. 
25. Ruebush II TK, Chisholm ES, Sulzer AJ. Development and persistence of antibody in persons infected with Babesia microti. American Journal of Tropical Medicine and Hygiene 30: 291292,1981.

26. Saal JR. Giemsa stain for the diagnosis of bovine Babesiosis. II. Changes in erythrocytes infected with Babesia bigemina and B. argentina. Journal of Protozoology 11: 582-585, 1964.

27. Suarez M, Alonso M, Pelaez R, Sanchez B, Bravo JR, Sanchez A. Investigation of Babesia in farm workers and blood donors in the province of Ciego de Ávila. Revista Cubana de Medicina Tropical 49: 130-135, 1997.
28. Sun T, Tenenbaum MJ, Greenspan J, Teichberg S, Wang RT, Degnan T, Kaplan MH. Morphologic and clinical observations in human infection with Babesia microti. Journal of Infectious Disease 148: 239-248, 1983.

29. Wright IG, Goodger BV, Buffington GD, Clarck IA, Parrodi F, Waltisbuhl DJ. Immunopathophysiology of babesial infections. Transactions of the Royal Society of Tropical Medicine and Hygiene 83: 11-13,1989.

30. Wright IG, Goodger BV, Clark IA. Immunopathophysiology of Babesia bovis and Plasmodium falciparum infections. Parasitology Today 4:214-218, 1988. 